\title{
LV. Additional remarks on isomorphism
}

\author{
H.J. Brooke Esq. F.R.S. L.S.\&G.S.
}

To cite this article: H.J. Brooke Esq. F.R.S. L.S.\&G.S. (1831) LV. Additional remarks on isomorphism , Philosophical Magazine Series 2, 10:60, 424-425, DOI: 10.1080/14786443108674300

To link to this article: http://dx.doi.org/10.1080/14786443108674300

曲 Published online: 14 Jul 2009.

Submit your article to this journal ¿

山 Article views: 3

Q View related articles ¿ 


\section{Mr. Brooke's Additional Remarks on Isomorphism.}

candens. M. (white trailing hispid):

a minus : foliis magis candentibus. Flores (duos solùm vidi) terminales in ramulis lateralibus, solitarii parvi albi concinni antemeridiano, mox erubescentes, denique lætè rubicundi. Cæteri ordinarii.

Floret Junii mense. G. H. $々$.

$\beta$ viridius, duplò majus omni parte, foliis viridioribus floribus (horum 2 solùm vidi) albis seu niveis pulchrioribus mox erubescentibus, denique altè rubicundis, antemeridianis.

Floret Septembris mense. G. H. $h$.

Obs. 3. Rami prostrati hujus speciei ex eorum nodis valdè radicant, uti Fragrariae sarmenti.

LV. Additional Remarks on Isomorphism. By H.J. BrookE, Esq. F.R.S. L.S.\&. G.S.**

IN the appendix to a work just published by Dr. Daubeny on the Atomic Theory, some observations are inserted relative to a paper of mine on Isomorphism, inserted in No. 57 of this Journal.

Upon these observations I shall at present only remark, that they contain two paragraphs upon which I am desirous of immediately setting myself right with Dr. Daubeny and the readers of his work.

Dr. Daubeny says, "It seems impossible to apply the [theory of mixture of foreign matter] to the garnet species, neither has Mr. Brooke attempted to do so."

What mineral is it, I should first be disposed to inquire, that is to be designated by the name of Garnet? It is not denoted by its crystalline form, for that is common to a variety of others; and there is no very apparent reason why, among the substances which, chiefly on account of their similar forms, have been included under the supposed garnet tribe, there should not be some, which, on account of their chemical differences, do really constitute distinct species. To enter, however, upon an investigation of this question would require a knowledge of the chemical constitution of the matrices or rocks in which the several varieties have been found;-a point upon which scarcely any correct information can be collected from the published works on the subject. And probably on reconsideration Dr. Daubeny will be of opinion, that the garnets are, from the class of forms to which

* Communicated by the Author. 
Mr. Brooke's Additional Remarks on Isomorphism. 425

they belong, the last which ought to be adduced as evidence either of the truth or fallacy of isomorphism.

The second paragraph to which I have alluded is as follows:-

"It may be remarked, that in the case of Stilbite rohich Mr. Brooke has brought forward as an exception, he has overlooked the presence in it of 6 atoms of water,-a circumstance which constitutes a chemical difference between that mineral and paranthine."

This however involves an entire misrepresentation of what I have stated ; - unintentional I have no doubt, and occasioned by hasty perusal of what I wrote. I did not, as Dr. Daubeny will perceive on looking again at my paper, raise any question about the form of Stilbite. I referred to Eudyalite as an example in which soda and lime are said to be isomorphous in respect of 1 atom of silica; to Paranthine, in which they are said to be isomorphous in respect of 2 atoms of silica; and to Siilbite, in which they stand in the same relation to 3 atoms of silica. And I did this merely to adduce the inference that all other elements which might be supposed isomorphous in respect of 1 atom of silica, ought to be equally so when combined with 2 atoms, or with 3 atoms; and hence it was unnecessary even to consider the water or any of the other component elements of either of these minerals.

With regard to plesiomorphism, it does not appear that any limit has been assigned to the difference in the plesiomorphous angles. Silica and alumina are said to be isomorphous when alumina acts the part of an acid. But as the question raised is, whether the atoms of silica and alumina are isomorphous,-unless those of alumina differ according as this substance acts the part of acid or of base, and in this case it is not easy to conceive what an atom means, - silica and alumina should be isomorphous generally. Now the primary form of silica, or quartz, is a rhomboid of $94^{\circ} 15^{\prime}$, and that of alumina, or corundum, also a rhomboid, but measuring $86^{\circ} 5^{\prime}$. Hence these bodies are, when they occur singly, only plesiomorphous, with a difference in their angles of $8^{\circ} 10^{\prime}$, notwithstanding which they are required by the theory to pass for strictly isomorphous elements when alumina becomes a substitute for silica. When however they enter into mutual combination in cyanite, which is regarded as a pure silicate of alumina, both isomorphism and plesiomorphism at once vanish, and a new class even of form is produced, a doubly oblique prism, as irregular and remote a form from the rhomboid as can be found amongst crystals.

How these facts are to be reconciled with the new theory,

I must leave to the better consideration of its supporters.
N.S. Vol. 10. No. 60. Dec. 1831.
3 I
LVI. Notices 